\title{
Cyclones over Fram Strait: impact on sea ice and variability
}

\author{
Burghard Brümmer, Gerd Müller, Björn Affeld, \\ Rüdiger Gerdes, Michael Karcher \& Frank Kauker
}

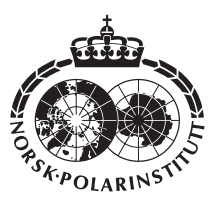

\begin{abstract}
The relation between sea ice drift and cyclone activity in the Fram Strait region was studied by both in situ observations and long-term time series. In a 1999 field campaign, the atmospheric forcing and the ice drift were determined using a research aircraft and drifting ice buoys. One cyclone entered the experimental area and caused a temporal increase in ice drift speed. Long-term studies are based on 16 years of cyclone statistics and model, satellite and sonar ice drift estimates. The actual impact of a cyclone depends on its particular track through Fram Strait. On the average, cyclones increase the Arctic ice export through Fram Strait.
\end{abstract}

B. Brümmer, G. Müller \& B. Affeld, Meteorological Institute, University of Hamburg, Bundesstraße 55, D-20146 Hamburg, Germany; R. Gerdes, M. Karcher \& F. Kauker, Alfred Wegener Institute for Polar and Marine Research, Kolumbusstraße, D-27568 Bremerhaven, Germany.

Processes in Fram Strait have a high potential to affect the climate of the North Atlantic. The most important one is the ice transport from the Arctic Ocean into the Atlantic Ocean. Per annum, about $10-20 \%$ of the Arctic sea ice is transported through Fram Strait (e.g. Häkkinen 1993; Bitz et al. 1996). The freshwater export influences the oceanic density stratification and hence the conditions for deep convection in the Greenland Sea, which is considered to be an important driving mechanism for global oceanic circulation - what is known as the "conveyor belt".

Ice drift through Fram Strait shows variability on many time scales. The inter-annual variability is almost as large as the long-term average (Harder et al. 1998). Is the variability of the ice export connected with atmospheric cyclones and their variability?

The potential importance of Fram Strait cyclones for the ice drift became evident from observations performed during the ARKTIS 1993 experiment, when a relatively small (diameter about $200 \mathrm{~km}$ ) and shallow (vertical extension about $2 \mathrm{~km}$ ) cyclone moved northward over the sea ice and caused a substantial increase in wind factor. The ratio of ice drift to wind speed increased from $5 \%$ before to $9 \%$ after the cyclone's passage, presumably by break-up (changing non-free ice drift towards free ice drift) or by ridging (increase of wind drag) (Brümmer $\&$ Hoeber 1999). This observation initiated further investigations of the cause, impact and variability of Fram Strait cyclones. First results are represented below. The methods are (a) case studies of individual Fram Strait cyclones based on field observations and (b) statistical investigations of Fram Strait cyclones and ice export based on long-term time series.

\section{Case study}

\section{Observational platforms}

In April 1999, the field experiment FRAMZY (short for Framstrassen-Zyklonen) (Brümmer 2000) was performed to investigate the properties of Fram Strait cyclones and their effect on sea ice drift. For this purpose, 14 ice buoys were deployed within an area of $200 \mathrm{~km} \times 200 \mathrm{~km}$ on the ice of the East Greenland Current. The German Falcon 20 research aircraft performed five flight missions (10, 12, 14, 18 and 19 April 1999) over the ice buoy array in order to record the 

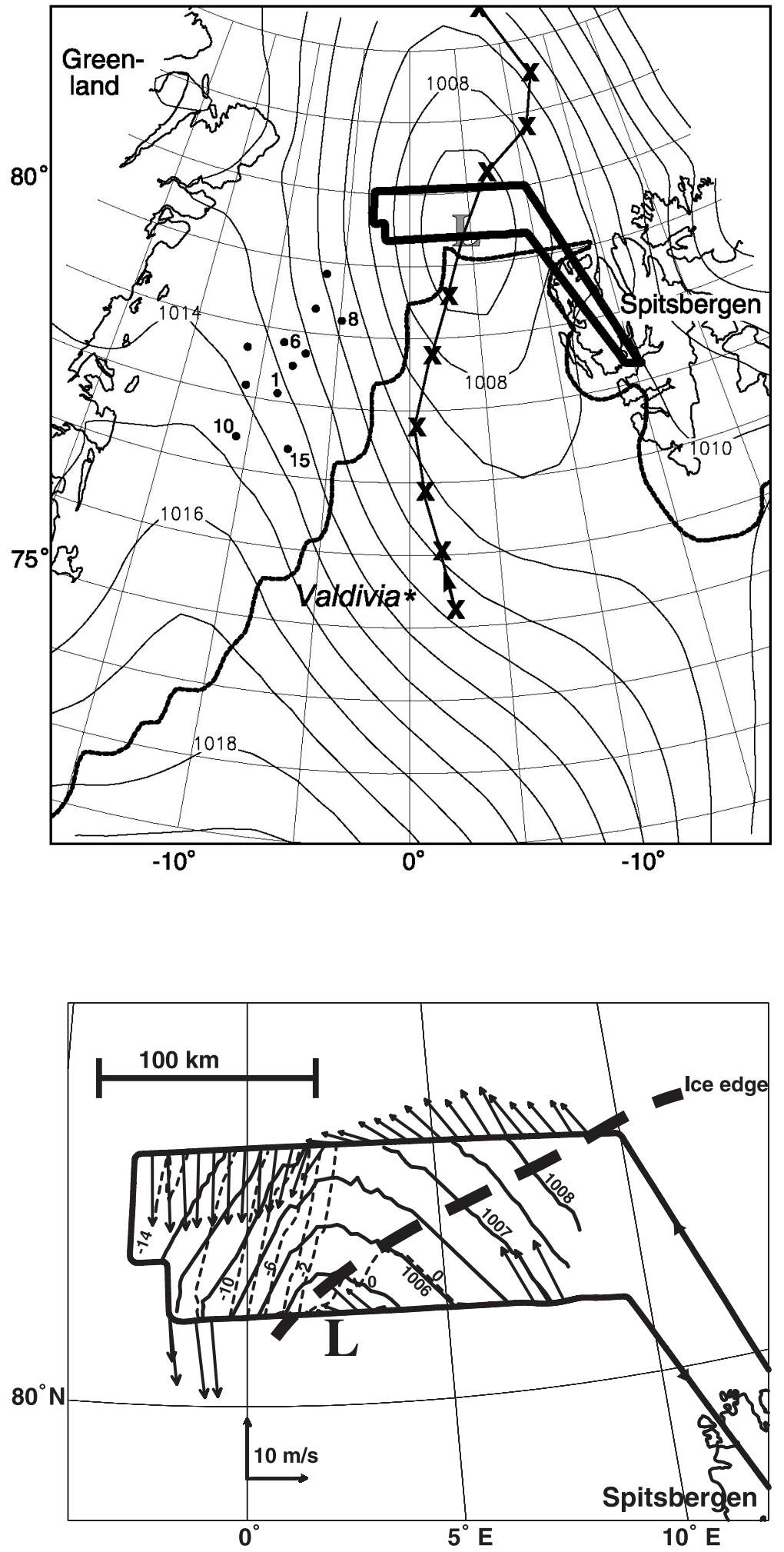

Fig. 1. Sea level pressure from ECMWF analysis data, flight pattern of the Falcon research aircraft (thick line), position of German research vessel $\mathrm{Val}$ divia, and positions of ice buoys (points) on 19 April 1999 12 UT. Crosses indicate sixhourly locations of the cyclone centre between 18 April 1999 00 UT (southernmost position) and 20 April 12 UT (northernmost position).
Fig. 2. Flight pattern of Falcon research aircraft (thick solid line) and observed ice edge (thick dashed line) on 19 April 1999. Sea level pressure isobars (thin solid line), air temperature isotherms (thin dashed line), and wind speed and direction (arrows) from measurements gathered during lowlevel runs $(\mathrm{z}<70 \mathrm{~m})$ between 10:20 UT and 11:40 UT. The wind vectors are averaged over a flight distance of about $1 \mathrm{~km}$. 
Fig. 3. Drift speed of ice stations 1, 8, 6, 10 and 15 (see Fig. 1 for positions). For better comparison, traces of stations 1, 6 and 15 are bold. The speed scale is valid for station 1 . The other curves are shifted downward by $0.2 \mathrm{~m} / \mathrm{s}$ each.

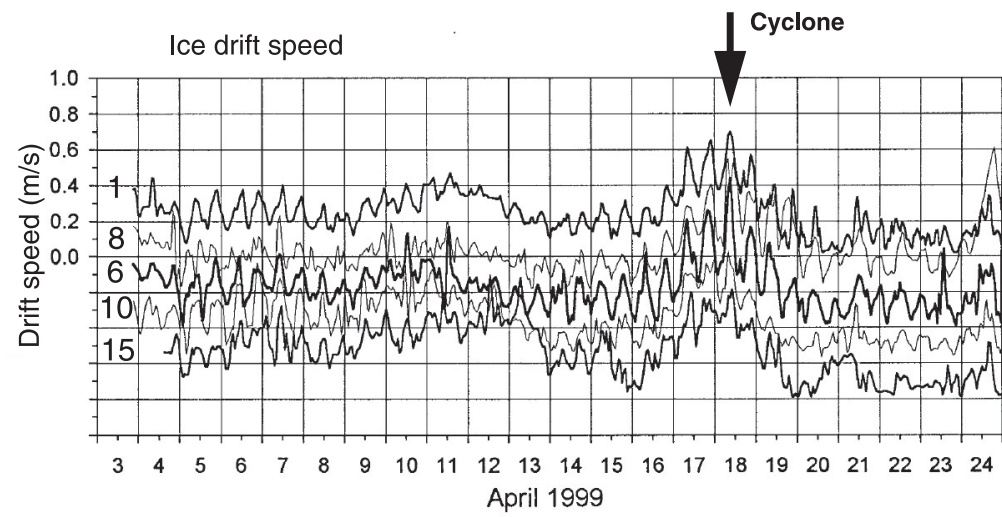

three-dimensional structure of the atmosphere as well as turbulent fluxes, the atmospheric forcing of the sea ice, surface temperature and albedo. The German research vessel Valdivia served as a continuously measuring meteorological station and as radiosonde station in the Greenland Sea.

\section{Observation of a Fram Strait cyclone}

During the two week long main phase of the experiment only one cyclone passed the experimental area. This is at the lower end of cyclone frequency in the Fram Strait area defined as the region $75^{\circ} \mathrm{N}-81^{\circ} \mathrm{N}$ and $20^{\circ} \mathrm{W}-15^{\circ} \mathrm{E}$. Based on six-hourly ECMWF (European Centre for Medium Range Weather Forecasting) analyses for the years 1985-1993, cyclone frequency ranges from 0 to 13 per month with an average of 6.25 cyclones per month (Brümmer et al. 2000).

The cyclone moved from the Norwegian Sea northward into the Fram Strait and crossed the ice border north-west of Spitsbergen on 19 April 1999. Figure 1 shows ECMWF surface pressure analysis for 19 April 1999 at 12 UT. At this time, the research aircraft crossed the cyclone's centre along the flight pattern shown. One day before, a flight mission took place within the north-west sector of the approaching cyclone. In addition, Fig. 1 shows the six-hourly locations of the cyclone centre between 18 April 199900 UT and 20 April 12 UT and the positions of the ice buoys.

The mesoscale fields of surface pressure, temperature, and wind measured within the cyclone on 19 April 1999 between 10:20 UT and 11:40 UT are presented in Fig. 2. The cyclone shows a warm southerly flow on its east side and a cold northerly flow on its west side. The temperature difference amounts to $15 \mathrm{~K}$. Vertical profiles (not shown) indicate that the cold air on the cyclone's west side had been confined below $\mathrm{z}=400 \mathrm{~m}$. Above this height, the temperature stratification above the cold side is similar to that above the warm side. The observed pressure field indicates a minimum of $1005 \mathrm{hPa}$ near the southern track of the flight pattern. This is about $2 \mathrm{hPa}$ lower than in the ECMWF analysis in Fig. 1. The wind along the northern track gradually veers from southeasterly on the warm side to northerly on the cold side of the cyclone. The southern track shows a similar wind pattern. Wind veering occurs over a very small distance in the middle of the southern track, indicating this point to be located very close to the centre of the cyclone.

The location of the ice edge as observed from the aircraft deviates from the ECMWF ice edge in Fig. 1, in which it is placed about $100 \mathrm{~km}$ too far southward. A detailed comparison between aircraft measurements within the FRAMZY cyclone and model analyses of ECMWF and German Weather Service is in preparation.

Figure 3 presents the drift speed of six ice buoys whose locations on 19 April 1999 at 12 UT are indicated in Fig. 1. The general drift direction was from the north-east towards the south-west. The drift is governed partially by the East Greenland Current and for the most part by the wind forcing. Drift speed was between 0.2 and $0.4 \mathrm{~m} / \mathrm{s}$ and had its highest values around $0.5 \mathrm{~m} / \mathrm{s}$ on 17/18 April, when the cyclone passed the buoy array. Apart from distinct increase in drift velocity on 17/18 April, the most conspicuous signal in 


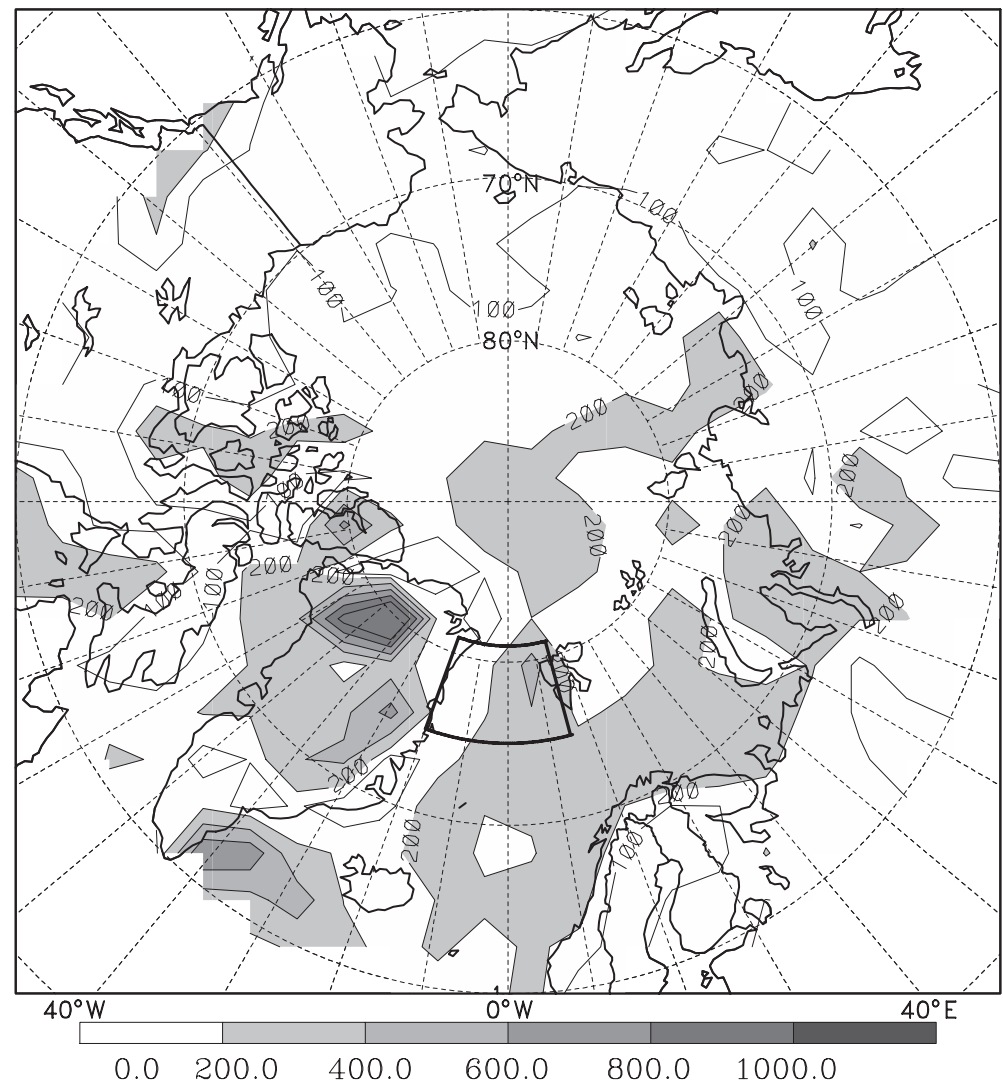

Fig. 4. Geographical distribution of cyclone detection frequency in the Arctic $\left(>60^{\circ} \mathrm{N}\right)$ for the winter months (November-April) based on ECMWF re-analysis data (1 December 1978 to 28 February 1994). Values greater than 200 cyclone detections during 6 months in a $300 \mathrm{~km} \times 300 \mathrm{~km}$ square are shaded. The area of the Fram Strait region is bounded in boldface lines. (The reason for the large local maximum in cyclone counts over Greenland is unknown and may be an artifact of the re-analysis data.) the time series is a modulation of approximately semidiurnal period, probably due to tidal effects or to inertial oscillations. Since the power spectral density of the drift speed (not shown) peaks at a frequency corresponding to a period of $12.4 \mathrm{~h}$, it is very likely that the modulation is at least partially due to semidiurnal lunar tide in the East Greenland Current region.

\section{Long-term variability}

\section{Cyclone statistics for the Arctic region}

Six-hourly ECMWF re-analysis data for the period from December 1978 to February 1994 have been used to elaborate a cyclone statistics for the Arctic region $\left(>60^{\circ} \mathrm{N}\right)$. This allows us to assess the cyclone activity in the Fram Strait with respect to that in the residual Arctic. The data have a grid resolution of $1.125^{\circ}$ in latitude and longitude. Thus, the horizontal west-east resolu- tion increases from $55.5 \mathrm{~km}$ at $60^{\circ} \mathrm{N}$ to $2.2 \mathrm{~km}$ at $88.875^{\circ} \mathrm{N}$. For spatial distribution maps a regular square grid with $300 \mathrm{~km}$ side length is used.

During the entire investigation period 136600 low pressure areas were detected (hereafter: cyclone detections) which belonged to 24116 different cyclones. This means that on average 6.13 cyclones are present in the Arctic at a particular time and the average lifetime is 5.66 six-hour intervals (ca. 34 hours). There is a clear annual cycle of cyclone frequency in the Arctic: a maximum in summer (May-October) and a minimum in winter (November-April). The annual cycle of Fram Strait cyclone frequency is the opposite; here, the maximum occurs in winter. Figure 4 shows the spatial distribution of cyclone frequency in the Arctic in winter. Fram Strait is a region of particularly high frequency.

\section{Cyclone statistics for the Fram Strait region}

Here, we define the area between $75^{\circ} \mathrm{N}$ and $81^{\circ} \mathrm{N}$ 

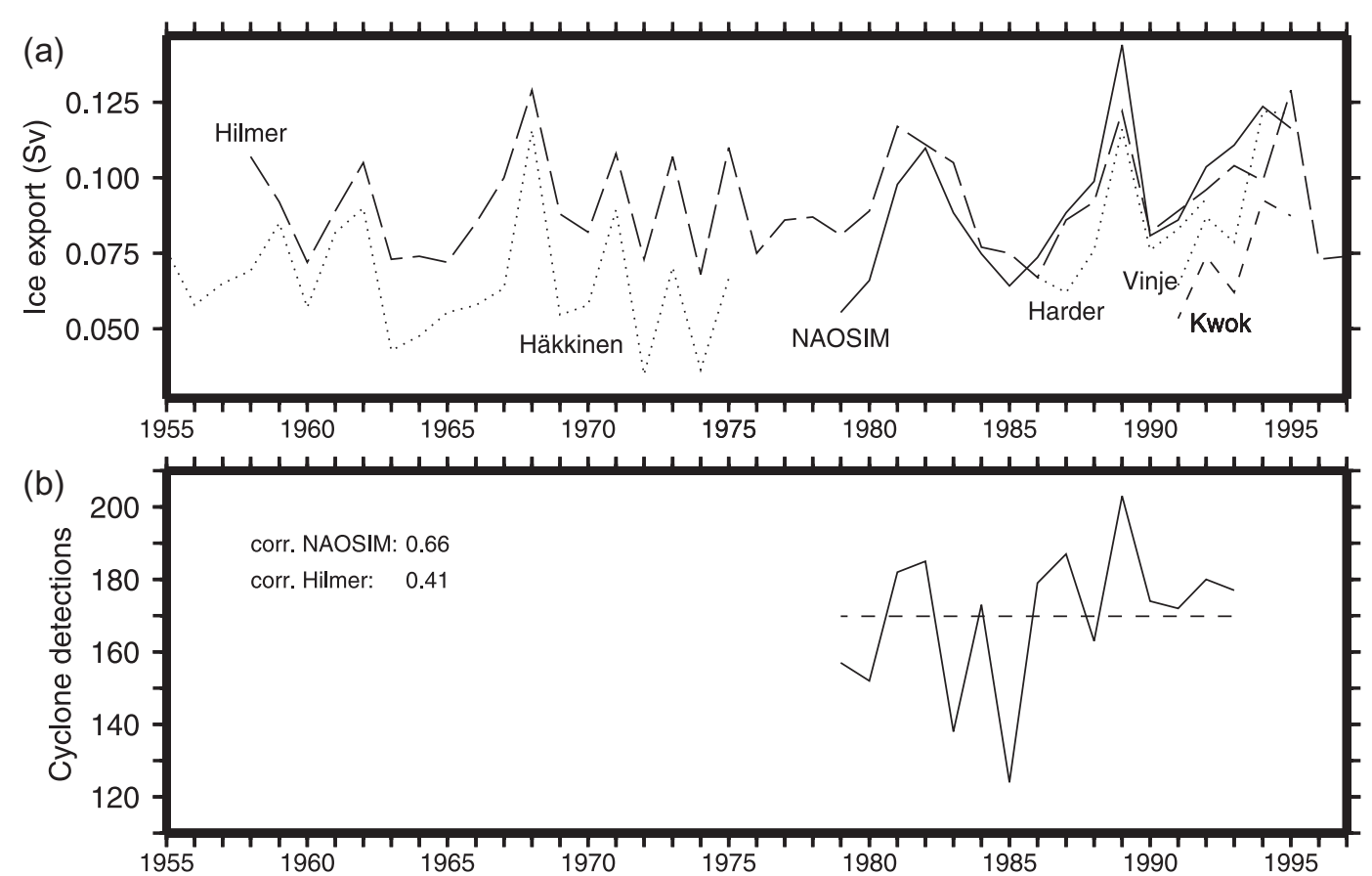

Fig. 5. (a) Time series of annual sea ice export through Fram Strait taken from Häkkinen (1993), Harder et al. (1998), Hilmer et al. (1998), Kwok \& Rothrock (1999) and Vinje et al. (1998) and calculated by NAOSIM (Karcher et al. unpubl. ms). (b) Annual number of cyclone detections in Fram Strait. Correlation coefficients (cyclone detections-NAOSIM, cyclone detections-Hilmer) are indicated.

and between $20^{\circ} \mathrm{W}$ and $15^{\circ} \mathrm{E}$ as the Fram Strait region (see Fig. 4). During the 15 years and 3 months long investigation period, 2586 cyclone detections were made belonging to 939 different cyclones. The annual cyclone detection frequency has values between 124 and 203 (see Fig. 5). On a monthly resolution the values range from 1 to 33. The average residence time of a cyclone in Fram Strait is 16.5 hours. This timescale makes clear that the direct influence of a cyclone on the Fram Strait ice drift is generally briefer than one day, although the indirect impact may last much longer.

\section{Cyclone-sea ice drift interaction}

The inter-annual variation of ice export through Fram Strait for 1955-1997 is shown in Fig. 5, together with the number of cyclone detections for the period 1979-1993. The ice export is estimated from simulations with the North Atlantic/ Arctic Ocean Sea Ice Model NAOSIM (Karcher et al. unpubl. ms) and other simulations (Häkkinen 1993, Harder et al. 1998, Hilmer et al. 1998) as well as from observations (Vinje et al. 1998; Kwok \& Rothrock 1999) and holds for a line between north-east Greenland and north-west Spitsbergen. Figure 5 implies that there are phases of coherent variations (1980-83 and 1988-1992) of ice export and cyclone frequency in the sense that increased cyclone frequency is connected with increased ice export, and non-coherent variations (1984-87).

To obtain further insight into the relation between cyclone frequency and ice export, the ice export was investigated separately for situations with and without a cyclone being present in Fram Strait. For this purpose, not the ice export itself but its deviation from the mean annual cycle was used. In addition, the Fram Strait region (see Fig. 4) was subdivided into four sectors along $78^{\circ} \mathrm{N}$ and $2.5^{\circ} \mathrm{W}$. The investigation was made with sixhourly ice export modelled by NAOSIM (Karcher et al. unpubl. ms) which was forced with daily 
means of ECMWF re-analysis data. Only the ice export data by NAOSIM are applicable for this study because they are available with the required high time resolution. The results in Table 1 show that the number of cyclone detections in Fram Strait is largest in the south-east sector and smallest in the north-west sector. On the average the ice export is increased when cyclones are present in Fram Strait. This effect is largest when the cyclones are in the south-east sector of the Fram Strait region. In this situation a north-east air flow on the rear side of the cyclone occurs at $80^{\circ} \mathrm{N}$, the latitude for which the ice export was determined. In this case, the ice export is increased, on average, by about $50 \%$ of the overall mean ice export, which is about $0.085 \mathrm{~Sv}$.

\section{Concluding remarks}

In situ observations of Fram Strait cyclones are rare. Apart of the above-mentioned cyclone observation (Brümmer \& Hoeber 1999) and the rather casual observations during CEAREX 1989 (Rasmussen et al. 1997), the data basis on Fram Strait cyclones was improved only slightly by the FRAMZY 1999 observation. The ARKTIS 1993 cyclone developed due to baroclinicity near the ice edge in the northern part of Fram Strait. It revealed a mesoscale extension (radius about $200 \mathrm{~km}$ ), was essentially restricted to the lowest $2 \mathrm{~km}$ of the atmosphere and its passage affected the ice drift by almost doubling the wind factor.

In contrast to the ARKTIS 1993 case, the FRAMZY 1999 cyclone was clearly above the mesoscale. It developed outside and moved into the Fram Strait and showed up weakly in the $500 \mathrm{hPa}$ level. Its passage caused a temporal increase in ice drift speed. The temperature con-

Table 1. Number of cyclone detections (January 1979-February 1994) and mean difference of sea ice export during cyclone detection to annual cycle of sea ice export in different Fram Strait sectors. Sea ice export from Karcher et al. (unpubl. ms).

\begin{tabular}{lccc}
\hline $\begin{array}{c}\text { Fram Strait } \\
\text { sector }\end{array}$ & $\begin{array}{c}\text { Number of } \\
\text { cyclone } \\
\text { detections }\end{array}$ & $\begin{array}{c}\text { Mean difference } \\
\text { of sea ice export }\end{array}$ & $\begin{array}{c}\text { Standard } \\
\text { deviation }\end{array}$ \\
\hline north-west & 217 & $-0.0069 \mathrm{~Sv}$ & 0.1024 \\
north-east & 627 & $+0.0179 \mathrm{~Sv}$ & 0.1024 \\
south-west & 699 & $+0.0077 \mathrm{~Sv}$ & 0.1091 \\
south-east & 1022 & $+0.0383 \mathrm{~Sv}$ & 0.1010 \\
total & 2565 & $+0.0211 \mathrm{~Sv}$ & 0.1048 \\
\hline
\end{tabular}

trast between the warm and the cold side of the FRAMZY 1999 cyclone was confined to a surprisingly shallow layer of only $400 \mathrm{~m}$.

In the Fram Strait region there is a high cyclone activity, especially in winter, compared to the residual Arctic. Fram Strait cyclones clearly influence the ice export depending on their passage through the Fram Strait. Taken together, cyclones in Fram Strait appear to increase the ice export. Cyclones may increase ice export by up to $50 \%$ of the average ice export.

Acknowledgements.-This work was supported by the German Science Foundation within the project SFB 512 Tiefdruckgebiete und Klimasystem des Nordatlantiks. NAOSIM model simulations have been performed as part of the EU programme Variability of Exchanges in the Nordic Seas (VEINS) . Funding by the European Commission is greatly appreciated.

\section{References}

Bitz, C. M., Battisti, D. S., Moritz, R. E. \& Beesley, J. A. 1996: Low-frequency variability in the Arctic atmosphere, sea ice, and upper ocean climate system. J. Clim. 9, 394-408.

Brümmer, B. (ed.) 2000: Field experiment FRAMZY 1999: cyclones over the Fram Strait and their impact on sea icefield report with examples of measurements. Ber. Zent. Meeres- $u$. Klimaforsch. Reihe A 33. Meteorological Institute, University of Hamburg.

Brümmer, B. \& Hoeber, H. 1999: A mesoscale cyclone over the Fram Strait and its effects on the sea ice. J. Geophys. Res. 104(D16), 19085-19098.

Brümmer, B., Thiemann, S. \& Kirchgäßner, A. 2000: A cyclone statistics for the Arctic based on European Centre re-analysis data. Meteorol. Atmos. Phys. 75, 233-250.

Häkkinen, S. 1993: An Arctic source for the great salinity anomaly: a simulation of the Arctic ice-ocean system for 1955-1975. J. Geophys. Res. 98(C9), 16397-16410.

Harder, M., Lemke, P. \& Hilmer, M. 1998: Simulation of sea ice transport through the Fram Strait: natural variability and sensitivity to forcing. J. Geophys. Res. 103(C3), 5595-5606.

Hilmer, M., Harder, M. \& Lemke, P. 1998: Sea ice transport: a highly variable link between Arctic and North Atlantic. Geophys. Res. Lett. 25, 3359-3362.

Karcher, M. J., Gerdes, R., Kauker, F. \& Koeberle, C. unpubl. ms: Propagation of hydrographic anomalies in the Nordic seas.

Kwok, R. \& Rothrock, D. A. 1999: Variability of Fram Strait ice flux and North Atlantic Oscillation. J. Geophys. Res. 104(C3), 5177-5189.

Rasmussen, E. A., Guest, P. S. \& Davidson, K. L. 1997: Synoptic and mesoscale atmospheric features over the ice-covered portion of the Fram Strait in spring. J. Geophys. Res. 102(D12), 13975-13986.

Vinje, T., Nordlund, N. \& Kvambekk, A. 1998: Monitoring ice thickness in Fram Strait. J. Geophys. Res. 103(C5), 10437-10449. 